\title{
National Defence, Self-Defence, and the Problem of Political Aggression
}

\author{
Seth Lazar*
}

\subsection{Introduction}

Wars are large-scale conflicts between organized groups of belligerents, which involve suffering, devastation, and brutality unlike almost anything else in human experience. Whatever one's other beliefs about morality, all should agree that the horrors of war are all but unconscionable, and that warfare can be justified only if we have some compelling account of what is worth fighting for, which can justify contributing, as individuals and as groups, to this calamitous endeavour.

Although this question should obviously be central to both philosophical and political discussion about war, it is at the forefront of neither. In recent years, philosophical discussion of warfare has bloomed, but the debate has focused on whom we may kill, on the assumption that our aims are justified. ${ }^{1}$ Political debate, meanwhile, is more concerned with matters of prudence, international law, and public justification, than with reassessing what is worth fighting for. ${ }^{2}$

\footnotetext{
* This chapter was initially conceived while at the institute for Ethics, Law and Armed Conflict, University of Oxford. It was written while a Research Fellow at the Centre for Moral, Social and Political Theory, in the School of Philosophy, ANU, and completed under an ARC Discovery Early Career Research Award. Earlier versions were presented at Henry Shue's war workshop, the second ELAC annual conference, and at the ANU. Many thanks to the audiences of those talks, and in particular to Henry Shue, David Rodin, Cécile Fabre, Jeff McMahan, and Christian Barry.

${ }^{1}$ For an overview of the recent debate, see Seth Lazar, 'War', in Hugh Lafollette (ed.), International Encyclopaedia of Ethics (Oxford: Wiley Blackwell, 2013). Please

${ }^{2}$ For example, of the five different inquiries into British participation in the Iraq war carried out in recent years, only the Chilcot Inquiry had the purposes and legality of the invasion within its remit, and rems to beseen how prominent a role this will play in its final report, as contrasted with the emphasis on pro Sees. Richard Norton-Taylor, 'Iraq War Inquiry Report Delayed', The Guardian, 16 November 2011; Mark Tran, 'Q\&A the Iraq War Inquiry', The Guardian, 24 November 2009. Similarly, the 2010 Strategic Defence Review, which had the remit to consider the whole military posture of the United Kingdom, confined itself
} 
For wars of intervention to halt or prevent massive humanitarian crises, this gap is not so troubling. When warfare is the only means to prevent the mass killing or enslavement of the innocent, the purposes of military force are clear enough (though undoubtedly many other problems remain). The problem is more pressing, however, for the justification of national defence. ${ }^{3}$ Although common-sense morality and international law view national defence as the paradigm case of justified warfare, grounding this consensus is surprisingly difficult. ${ }^{4}$ We typically believe that any state is justified in using lethal force to protect its territory against any form of uninvited military incursion by any other state. And yet we lack a good argument to explain why this should be so.

In this chapter, I explain why one familiar and otherwise plausible approach to the justification of killing in war cannot adequately ground common-sense views of permissible national defence. ${ }^{5}$ Reductionists believe that justified warfare reduces to an aggregation of acts that are justified under ordinary principles of interpersonal morality. ${ }^{6}$ The standard form of reductionism focuses on the principles governing killing in ordinary life, specifically those that justify intentional killing in self- and other-defence, and unintended but foreseen (for short, collateral) killing as a lesser evil. Justified warfare, on this view, is no more than the coextension of multiple acts justified under these two principles.

Reductionism is the default philosophical approach to thinking through the ethics of killing in war. It makes perfect sense to ask what principles govern permissible killing in general, before applying them to the particular context of war. If it cannot deliver

to budgetary questions, without asking just what we should be using our military for. See David Rodin, 'Defence Review Is an Opportunity, Not a Threat, to Our Military',

http://www.guardian.co.uk/commentisfree/2010/oct/13/defence-review-is-opportunity-not-threat (accessed 28 December 2011).

${ }^{3}$ This locution is somewhat unfortunate, because, on most accounts, rights of national defence accrue to states, not to nations.

${ }^{4}$ The most coherent articulation of conventional views about the ethics of war remains Michael Walzer's classic, Just and Unjust Wars: A Moral Argument with Historical Illustrations (New York: Basic Books, 2006). For international law governing the permissibility of armed resistance against armed attack, see, for example, article 51 of the UN Charter, and the recent Annex to the Rome Statute of the International Criminal Court.

${ }^{5}$ Obviously to justify warfare we have to justify other acts besides killing; clearly, however, if the killing cannot be justified, then the rest of the discussion is moot.

${ }^{6}$ The term is coined in David Rodin, War and Self-Defence (Oxford: Clarendon Press, 2002): 124. The most prominent exemplar is Jeff McMahan, see for example Jeff McMahan, 'War as Self-Defence', Ethics \& International Affairs, 18/1 (2004), 75-80. Other adherents include Richard J. Arneson, 'Just Warfare Theory and Noncombatant Immunity', Cornell International Law Journal, 39 (2006), 663-88; Tony Coady, 'The Status of Combatants', in David Rodin and Henry Shue (eds.), Just and Unjust Warriors: The Moral and Legal Status of Soldiers (Oxford: Oxford University Press, 2008), 153-75; Cécile Fabre, A Cosmopolitan Theory of the Just War (Oxford: Oxford University Press, 2012); Helen Frowe, 'Self-Defence and the Principle of Non-Combatant Immunity', Journal of Moral Philosophy, 8/4 (2011) 530-46; Lionel McPherson, 'Innocence and Responsibility in War', Canadian Journal of Philosophy, 34/4 (2004), 485-506; Seumas Miller, 'Civilian Immunity, Forcing the Choice, and Collective Responsibility', in Igor Primoratz (ed.), Civilian Immunity in War (Oxford: Oxford University Press, 2007), 113-35; Gerhard Øverland, 'Killing Civilians', European Journal of Philosophy, 13/3 (2005), 345-63; David Rodin, 'The Moral Inequality of Soldiers: Why Jus in Bello Asymmetry Is Half Right', in Rodin and Shue (eds.), Just and Unjust Warriors, 44-68. 
a plausible set of conclusions about when national defence is permitted, then we must either revise our beliefs about which conclusions count as plausible, or else face the significant challenge of developing a different theoretical model for justifying warfare-an exceptionalist model, which views war as an exception to the regular moral landscape, to which principles apply which apply to nothing else but war.7 We must show, in other words, that there is something worth fighting for in wars of national defence, which is not engaged when we use force in any other context.

The chapter proceeds as follows. Section 2.2 sets out the argument against reductionism. ${ }^{8}$ Section 2.3 considers and rebuts one common response to the argument, which has often been thought sufficient grounds to disregard its conclusion. Section 2.4 then asks whether a modified reductionism would survive unscathed by the argument. Finally, section 2.5 sets out some desiderata on a plausible exceptionalist alternative. Section 2.6 concludes.

\subsection{The Argument from Political Aggression}

The argument from political aggression, sometimes also called the bloodless invasion objection, is conceived as a reductio ad absurdum of standard reductionism. The following is an attempt to render it as precise as possible (commentary follows):

1. The reductionist theory of the ethics of war states that permissible acts of killing in war are permissible under the relevant principles of ordinary interpersonal morality.

2. The relevant principles of ordinary interpersonal morality are those justifying intentional killing in self-defence, and collateral killing as a lesser evil.

3. On the most permissive plausible account of self-defence, B may intentionally kill $\mathrm{A}$ in self-defence to avert an unjustified threat $\mathrm{T}$ only if either

a. T will harm some person's lesser interests, and A has culpably contributed to $\mathrm{T}$ or

b. T will harm some person's vital interests, and A has culpably or nonculpably contributed to $\mathrm{T}$.

\footnotetext{
7 Walzer for the most part simply assumed exceptionalism, without seeking to defend it (although see Walzer, Just and Unjust Wars, 128 and Michael Walzer, 'Response to McMahan's Paper', Philosophia, 34/1 (2006), 43-5. While others have recognized the flaws in reductionism (e.g. Henry Shue, 'Do We Need a Morality of War?', in David Rodin and Henry Shue (eds.), Just and Unjust Warriors, 87-111.), I am not aware of any fully-fledged attempt to provide plausible foundations for an exceptionalist alternative. Although see Yitzhak Benbaji's work, for one possible counterexample Yitzhak Benbaji, 'A Defence of the Traditional War Convention', Ethics, 118/3 (2008), 464-95; Yitzhak Benbaji, 'The Moral Power of Soldiers to Undertake the Duty of Obedience', Ethics, 122/1 (2011), 43-73 and chapter 7 in this volume. Please provide volume number and page range for the reference

${ }^{8}$ This argument is an attempt at a more precise and compelling formulation of a familiar objection, discussed for example by Richard Norman and David Rodin. See Richard Norman, Ethics, Killing and War (Cambridge and New York: Cambridge University Press, 1995), 133; Rodin, War and Self-Defence, 133-8, and chapter 4 in this volume.
} 
4. On the most permissive plausible account of collateral killing, B may collaterally kill $\mathrm{C}$ to avert outcome $\mathrm{O}$ only if either

a. O involves harm to some person's lesser interests, and C has culpably contributed to $\mathrm{O}$ or

b. O involves harm to some person's vital interests, and C has culpably or nonculpably contributed to $\mathrm{O}$.

5. In wars against aggression, the aggressor cannot be repelled without

a. Intentionally killing many people who have not culpably contributed to the outcome that we thereby avert and

b. collaterally killing many people who have not culpably contributed to the outcome that we thereby avert.

6. There are some purely political wars, in which the aggressors threaten only the victims' interests in their state's continued political control of some territorytheir purely political interests.

7. Individuals' purely political interests are not among their vital interests.

8. A theory of the ethics of war that cannot endorse lethal defence against purely political aggression should be rejected on those grounds.

$\mathrm{C} 1$ (from 2 to 7 ): Combatants fighting against a purely political aggression cannot, under the relevant principles of ordinary interpersonal morality, permissibly kill all the people whom they must kill in repelling the aggression.

$\mathrm{C}_{2}$ (from 1 and $\mathrm{C}_{1}$ ): Reductionism cannot justify fighting wars of defence against purely political aggression.

$\mathrm{C}_{3}$ (from $\mathrm{C}_{2}$ and 8): Reductionism should be rejected as a theory of the ethics of war.

Premise 1 formulates the genus reductionism, while premises 2 to 4 individuate one species, what I call standard reductionism. Premises 5 and 6 make descriptive claims about warfare in general, and a subset of actual and likely wars. Premise 7 is an evaluative claim, about the significance of the interests at stake in the wars described in premise 6. Premise 8 is likewise evaluative, positing that the ability to justify warfare against purely political aggression is a sine qua non of a plausible account of the ethics of war. The following subsections discuss each segment of the argument in greater depth.

\subsubsection{Standard reductionism}

The first four premises of the bloodless invasion objection formulate its target. Premise 1 is the most general; it simply identifies the defining commitment of a reductionist theory of the ethics of war. Premise 2 specifies the principles that, on the standard reductionist view, justify intentional and collateral killing in ordinary life. There are other possible variants of reductionism, which would not affirm premise 2. For example, a thoroughgoing act-consequentialist might contend that the relevant principle of interpersonal morality is 'maximize value. The objection targets only the standard form of reductionism (in section 2.4 below, I will consider whether reductionism can be saved from the bloodless invasion objection by proposing an alternative premise 2). 
Premises 3 and 4 each identify one feature of the relevant principles governing, respectively, self-defence justifications of intentional killing, and lesser evil justifications of collateral killing. ${ }^{9}$ The argument is intended to target all variants of standard reductionism, therefore it is important to remain neutral on most questions in the ethics of self-defence and collateral killing. The objection therefore focuses on one narrow area of each theory, one question to which any account of self-defence and collateral killing must have an answer: when is killing in self-defence, or collateral killing, proportionate? ${ }^{10}$ Satisfying proportionality is necessary but not sufficient to justify killing in self-defence or as a lesser evil. The other conditions on justified killing are not important for the present argument.

In general, the use of force to avert an outcome is proportionate if there is (at least) an appropriate fit between the force used, and the outcome averted. Precisely what this amounts to will depend on numerous factors. ${ }^{11}$ However, in extreme cases we know disproportionality when we see it: if A threatens to bruise B's leg, and B uses lethal defensive force to avert that threat, then B's action clearly does not satisfy proportionality; similarly, if B can avert the bruised leg only through action that kills $\mathrm{C}$, an uninvolved bystander, as a side-effect, then B's action again does not satisfy proportionality. In neither case does the relevant fit obtain.

The proportionality constraint on self-defence and collateral killing can be more or less permissive. The argument from political aggression contends that standard reductionism is insufficiently permissive to justify killing in wars against purely political aggression, so it is stronger the more permissive the variant of reductionism that we presuppose (since it will apply a fortiori to any more restrictive variant). Premises 3 and 4 therefore identify the most permissive plausible take on proportionality in self-defence and collateral killing.

In many legal systems, and in ordinary moral thinking as well, lethal defence is warranted only against an attacker who threatens the defender's vital interests. ${ }^{12}$ Since the argument depends only on claiming that purely political interests are not vital, we do not need a full list of which interests are vital. However, most will agree that our interests in not being killed, seriously wounded, or tortured, raped or kidnapped are sufficiently vital that we can justifiably kill in their defence. Conversely, some interests clearly fall below the relevant threshold of importance, for example my interest in retaining some particular sum of money, or in avoiding all physical harm whatsoever.

Although this view of proportionality in self-defence is widespread, some will regard it as insufficiently permissive. They think that the proportionality constraint limits us

\footnotetext{
9 This locution encompasses justifications for collateral killing that appeal to the doctrine of double effect.

${ }^{10} \mathrm{McMahan}$ calls proportionality in self-defence narrow proportionality, and in collateral harm wide proportionality Jeff McMahan, Killing in War (Oxford: Oxford University Press, 2009), 21.

${ }^{11}$ For a detailed discussion of some of these factors, see David Rodin, 'Justifying Harm', Ethics, 122/1 (2011), 74-110.

${ }^{12}$ For example, the Model Penal Code permits the use of deadly force in self-defence only to avert death, serious bodily injury, forcible rape, or kidnapping $(\$ 3.04(2)(b)(i))$.
} 
to killing in defence of our vital interests only if the person killed is morally innocent with respect to the threat we are thereby averting. However, if she is to some degree culpable for that threat, then lethal defence might be proportionate to protect even our less than vital interests. Her culpability justifies discounting her interests, so that it is proportionate to kill her to avert a threat which it would be disproportionate to kill her to avert, if she were innocent with respect to it. ${ }^{13}$ Precisely how that discount should be applied is open to debate. However, if our aim is still to ensure a fit between the threat averted and the defensive force used, then presumably the degree of discount should vary with the degree of culpability. The more culpable the target, the greater the discount applied to her interests. Thus when a target is barely culpable-for example because she has a strong but not complete excuse for her action that contributed to the threat - the discount will be less than when her contribution is without excuse, and the threat averted by killing her must be proportionally more serious.

This is the most permissive plausible position on proportionality in self-defence. As premise 4 suggests, proportionality in collateral damage should be in a similar way. How serious must the outcome averted by $\mathrm{B}$ be, to render killing $\mathrm{C}$ as an unintended but foreseen side-effect proportionate? ${ }^{14}$

At first glance, the most permissive view plausible would be that the prospective harm averted should at least be more than marginally greater than the harm suffered by C (i.e. death). This follows if we believe that people's interests enjoy moral protection over and above their impartially considered worth. If I can permissibly inflict $\mathrm{x}$ harm on you, in the course of averting $x+1$ harm to myself, then your interests enjoy no additional protection. ${ }^{15}$ They are merely quanta to be included in an overall aggregation of affected interests. Although a reductionist could hold this view, standard reductionism asserts that people's interests are protected by rights, so marginal interpersonal trade-offs of this sort are prohibited. If the victims of collateral harming are protected by rights against being harmed, as we will assume that they are, then the exchange rate between harm inflicted and averted must be steeper than this. The harm averted must be more than marginally greater than the harm inflicted. Since collateral killing involves irremediable harm to the victim's most vital interests, it can be justified only if we thereby protect the vital interests of a greater number of others.

${ }^{13}$ Kai Draper, 'Defence', Philosophical Studies, 145 (2009), 69-88: 81; Kimberly Ferzan, 'Justifying Self-Defence', Law and Philosophy, 24/6 (2005), 711-49: 735; Frances M. Kamm, 'Failures of Just War Theory: Terror, Harm, and Justice', Ethics, 114/4 (2004), 650-92: 676; Tziporah Kasachkoff, 'Killing in Self-Defence: An Unquestionable or Problematic Defence?', Law and Philosophy, 17/5 (1998), 509-31: 528-29; Jeff McMahan, 'Self-Defence and the Problem of the Innocent Attacker', Ethics, 104/2 (1994), 252-90: 26566; Rodin, 'Justifying Harm'; Daniel Statman, 'Can Wars Be Fought Justly? The Necessity Condition Put to the Test', Journal of Moral Philosophy, 8/3 (2011), 435-51: 683.

${ }^{14} \mathrm{I}$ am assuming that there is a morally relevant difference between collateral and intentional killing; some, of course, would deny this. However, they would presumably argue that collateral killing is as seriously wrong as intentional killing, not the other way round. Their view, therefore, would be more restrictive than those discussed here, and so would be vulnerable to the same criticisms.

${ }^{15}$ Seth Lazar, 'The Nature and Disvalue of Injury', Res Publica, 15/3 (2009), 289-304. 
There are two ways to make our account of proportionality in collateral harm more permissive. First, we can deploy just the same reasoning as applied in individual self-defence. When there is some reason to discount the interests of the victim of collateral harm, it can be proportionate to inflict that harm even if lesser interests are at stake. Hence 4 a mirrors $3 a .{ }^{16}$

Second, we might argue that individuals enjoy an agent-centred prerogative to give their own interests more weight in their moral reasoning than is warranted by their impartially considered worth. ${ }^{17}$ In that case, it might be possible to justify inflicting $\mathrm{x}$ harm on you, in order to avert $\mathrm{x}+1$, or even $\mathrm{x}$ harm to myself, without evincing disregard for your right not to be harmed. Although your right against being harmed puts a thumb in the scales for you, my agent-centred prerogative puts one in the scales for me too. However, even if we do endorse this agent-centred prerogative (which raises its own problems), it is surely implausible to suggest that B may collaterally kill C in the course of averting an outcome that threatens anything other than B's vital interests, at least provided $\mathrm{C}$ is morally innocent with respect to the outcome that $\mathrm{B}$ is aiming to avert.

In summary, on the most permissive plausible interpretation of ordinary interpersonal morality, unless there is some strong reason to discount our victim's interestsin particular, her culpability for the outcome that we are trying to avert-we may kill either collaterally or in self-defence only in the preservation of vital interests.

\subsubsection{Warfare and purely political aggression}

Premise 5 makes two descriptive claims about wars against aggression: that they cannot be fought without collaterally killing many people, and intentionally killing many others, who are not culpable for the outcomes we thereby avert. Note that warfare also involves much else besides these two classes of act. Nonetheless, for warfare to be justified, these collateral and intentional killings must be justified.

Premises $5 \mathrm{a}$ and $5 \mathrm{~b}$ do not specify necessary truths about warfare. It is possible to conceive of wars where neither claim holds. Nonetheless, in practice I think each is a truism, denial of which evinces a troubling misapprehension of the moral seriousness of war. If we could fight wars in which all those whom we killed were culpable for the threats that we seek to avert, then warfare would not seem such a dreadful thing. Although the good guys will undoubtedly suffer losses too, they can be sure that they will kill only the bad guys, so although there are prudential risks in war, there are no or few moral risks. It just seems wildly unrealistic to imagine that warfare could be so morally congenial. Even with all the time, effort, and institutional structures that we

\footnotetext{
${ }^{16}$ McMahan, Killing in War, 218.

${ }^{17}$ See e.g. Cécile Fabre, 'Permissible Rescue Killings', Proceedings of the Aristotelian Society, 109/1pt2 (2009), 149-64; Helen Frowe, 'A Practical Account of Self-Defence', Law and Philosophy, 29 (2010), 245-72; Jonathan Quong, 'Killing in Self-Defence', Ethics, 119/2 (2009), 507-37. For the idea of an agent-centred prerogative see Samuel Scheffler, The Rejection of Consequentialism (Oxford: Clarendon Press, 1994).
} 
put in place, we fail to ensure that only the guilty are harmed by our system of criminal justice. It would be extraordinary if, despite lacking any of the mechanisms by which the justice system targets its harms to the culpable, warfare were able to deliver results more congruent with people's degree of guilt.

Premise $5 \mathrm{~b}$ should go through unquestioned. The victims of collateral harms are usually (although not only) civilians (of either side-we are not solely concerned with collateral harms to the adversary, but to our co-citizens as well). Although counting the casualties of war is fraught with problems, as is drawing the line between civilians and combatants, and although highly inflated figures are often touted, even conservative estimates suggest that in recent wars civilians suffer in at least as great numbers as combatants..$^{18}$ As long as the battlefield is on populated territory, we can be quite sure that innocent people will be collaterally killed.

Some will be more sceptical about $5 \mathrm{a}$, the thesis that winning a war presupposes intentionally killing many innocent people. They will argue that wars can be won without ever intentionally killing noncombatants, and that all combatants are to some degree culpable for the threat that we avert by killing them. ${ }^{19}$ I have discussed each of these arguments in depth elsewhere; moreover, it is precisely the focus on this aspect of the ethics of war which this volume is intended to redress. ${ }^{20}$ Our goal here is to explore the purposes of military force, not to (again) consider the responsibilities of soldiers. Three observations, however, are in order.

First, the truth of $5 \mathrm{~b}$ (that warfare inevitably involves collaterally killing the innocent) is sufficient for the objection to go through. Premise 5a gives it more purchase, but is not necessary. Second, the objection would still have considerable force if we focused not on total innocence, but on near-innocence. As noted above, where someone is only marginally culpable for contributing to an unjustified threat that killing him helps to avert, the discount applied to his interests must be proportionate to his degree of culpability. Arguably where he is barely culpable, killing him to avoid a threat to lesser interests remains disproportionate. Third, the culpability of combatants can be diminished in two ways: by excuse, and by non-contribution. If victory presupposes intentionally killing combatants whose contribution to the outcome that we thereby avert is negligible or non-existent, then our basis for discounting their interests disappears. As I have argued elsewhere, and as Jeff McMahan notes in this volume: in

\footnotetext{
${ }^{18}$ Prompted by widespread touting of the claim that 90 per cent of the victims of war are civilians, Adam Roberts has offered a sceptical analysis of a wide range of datasets. His aim is to show that the idea of a 9:1 civilian to military casualty ratio is unfounded, but even on more measured evidence, civilians suffer at least as much, if not more than the military in modern wars. And not only in complex civil wars, note, where civilians are habitually targeted. Estimates for the 2003 invasion of Iraq, for example, suggest that between March 2003 and June 2006 between five and three civilians died for every military casualty (he cites the Brookings Institution Iraq Index, and the Iraq Body Count respectively). Adam Roberts, 'Lives and Statistics: Are 90\% of War Victims Civilians?', Survival, 52/3 (2010), 115-36.

19 See e.g. Rodin, 'Moral Inequality of Soldiers'.

${ }^{20}$ Seth Lazar, 'Responsibility, Risk, and Killing in Self-Defence', Ethics, 119/4 (2009), 699-728; Seth Lazar, 'The Responsibility Dilemma for Killing in War', Philosophy \& Public Affairs, 38/2 (2010), 180-213.
} 
warfare in general, and in purely political aggression in particular, the contribution made by any individual combatant to the purely political threat is negligible at best. ${ }^{21}$

Premise 6 identifies the class of wars of purely political aggression. While history is undoubtedly replete with its murderous marauders, who make death and suffering their aim, invaders' objectives are often more prosaic: mayhem is not their end, but their means; their goal is to attain some degree of political control of a territory and its population. They kill only because they have to; if their victims would submit at the outset, no blood would be shed. Their ultimate aims might be, among other possibilities, resource extraction, imposing an exogenous ideology on the invaded state's institutions, installing a more favourable government or simply glorifying their expanding empire. But their aims are exclusively political: they seek to change the institutional structure that governs people's lives in a territory, not to otherwise harm the people themselves. Since premise 6 is probably the most contentious part of the argument from political aggression, I will defend it in depth in section 2.3 below.

\subsubsection{Two evaluative claims}

Premises 7 and 8 make two evaluative claims; first that individuals' purely political interests are not vital, and second that we should reject a theory of the ethics of war that cannot endorse lethal defence against purely political aggression. Each is intended to be sufficiently intuitively plausible that it needs little further support-although of course one way to resist the force of the objection is to push back against these intuitions.

A full defence of premise 7 would require a full theory of well-being, which is obviously beyond the scope of this chapter. However, it is prima facie plausible: my interest in my state's retaining political control of a particular territory can hardly be ranked alongside my interest in life or bodily integrity, for example. Suppose the Scottish Nationalist Party held a successful referendum on independence from the United Kingdom, and subsequently seceded. English, Welsh, and Northern Irish citizens of the UK would accordingly suffer a decisive blow to their interest in their state having political control of the Scottish territory. But they have surely not suffered a loss in the order of being killed, kidnapped, or raped.

Perhaps we should distinguish between the interests of citizens of the invaded state who inhabit the invaded territory, and those who do not. For inhabitants of the invaded territory, are more potent interests at stake? They probably have a weighty interest in remaining in their homes, and indeed in their homeland-many people have a profound connection to each of these. ${ }^{22}$ However, a purely political aggressor will not expel inhabitants either from their home or from their homeland. Their goal is

\footnotetext{
${ }^{21}$ Lazar, 'Responsibility Dilemma'. See also McMahan, chapter 6 in this volume.

${ }^{22}$ See Thomas Hurka, 'Proportionality in the Morality of War', Philosophy \& Public Affairs, 33/1 (2005), 34-66: 55-6; McMahan, 'War as Self-Defence', 78.
} 
to take control of the institutions governing a territory, which is quite consistent with letting the present inhabitants remain.

However, what if the new institutional structure denies inhabitants of the occupied territory political representation? Their interest in enfranchisement is, again, greater than the mere interest in their state's continued political control of this territory. It is probably still not a vital interest, to preserve which we can justify killing the innocent. Suppose, for example, that A innocently prevents B from voting in an election-she has an accident outside B's home, which prevents him from driving to the polling station. Would B be justified in harming A in order to clear a path for his car? It seems very unlikely. However, what if A's obstruction is not merely a one-off, but recurs every time $B$ is supposed to vote. Would we think harming A permissible in this case? On the assumption that $\mathrm{A}$ is morally innocent, it still seems wrong to harm her in order to get to the polling station. This seems even clearer when it comes to collateral harm. Even a long-term disenfranchisement is not morally important enough to justify killing innocent people, whether intentionally or collaterally.

Even if these purely political interests were vital, the permissibility of defence against such aggression does not depend on whether the invader proposes to enfranchise the inhabitants of the newly acquired territory, or, indeed, on whether the inhabitants of that territory were enfranchised before the invasion.

Premise 8 is more controversial than premise 7 . Why should we think being able to justify this particular class of wars is so important? Why not, if the argument works out that way, simply reject our common-sense view of national defence? Two reasons stand out. First, international law and national military practices reflect a widespread practical commitment to the permissibility of lethal defence of sovereignty against purely political aggression. If we reject premise 8 , then we must reject this consensus, and endorse radical and revisionist political prescriptions. Second, I think that even in wars where there are significant threats to people's vital interests, part of what justifies fighting is the importance of preserving those states' political independence. Any account which restricts our understanding of the goals of war to those that are pursued in force outside of war is to that extent incomplete or misleading. While I concede that we do not always fight only for our country, it seems odd to deny that preserving political independence plays any substantial justifying role.

These are considerations in favour of premise 8 , not decisive arguments, and one response is simply to deny 8 , and so deny that the argument's conclusions are troubling - to simply bite the bullet, and say that we are indeed not permitted to use lethal force to avert purely political aggression. I think this would be a profoundly revisionist move, but perhaps profound revision is precisely what is needed here. ${ }^{23}$ For the sake of argument, however, let us assume that premise 8 is true, in which case the conclusions follow: under the relevant principles of ordinary interpersonal morality, we cannot

\footnotetext{
${ }^{23}$ Hence, in my view, David Rodin's position in his chapter in this volume is the most consistent option
} open to reductionists. 
justify lethal defence against purely political aggression, because the interests at stake are not vital, but fighting will necessarily involve killing the innocent, both intentionally and collaterally, thus both as a matter of self-defence and under the rubric of collateral killing, warfare is disproportionate, so impermissible. If we find premise 8 convincing, then this is grounds to reject standard reductionism, and if standard reductionism is the most permissive, plausible variant of reductionism, then reductionism itself must go too.

\subsection{Denying the Possibility of Purely Political Aggression}

The standard reductionist who wishes to reject the conclusion of the argument from political aggression can do so by rejecting one of premises 5 to 8 . I think the most interesting approach is to deny the evaluative claims in premises 7 or 8 . Perhaps the objection should give us grounds to rethink the importance of our purely political interests - that we believe them worth fighting for might indicate their innate worth. Developing an argument to this end would undoubtedly be challenging, since according to standard reductionism, institutions are wholly epiphenomenal to the morality of war, so it is hard to see how our interests in the continuation of a particular institutional arrangement could be worth killing for. However, perhaps such an argument could be provided, and if so it would certainly be a compelling addition to the reductionist armoury.

However, if the reductionist rejects premise 8, then there is no need for a developed theory of the moral importance of our purely political interests. In my view, while a properly developed argument against premise 7 would be interesting, consistency really demands that reductionists should reject premise 8 , and endorse their radically revisionist conclusions (this, indeed, was the attitude of Richard Norman and David Rodin, who presented the objection as a QED, not as a reductio). During the last two centuries, the morality of war has been almost universally assumed to be sui generis, a property of relations among states, not among individuals, such that the normative principles governing military conduct could not possibly be derived from the principles appropriate to individual action outside of war. ${ }^{24}$ Reductionism constitutes a profound, perhaps devastating challenge to this theoretical outlook-its principal contribution has been to radically undermine the most developed philosophical articulation of that conventional statist position, in Walzer's Just and Unjust Wars. ${ }^{25}$ It would be an extraordinary coincidence if this radical rethink of how we should justify killing in war should yield conclusions that are in practice coextensive with the exceptionalist

\footnotetext{
${ }^{24}$ See Gregory M. Reichberg, Henrik Syse, and Endre Begby, The Ethics of War: Classic and Contemporary Readings (Oxford: Blackwell, 2006).

${ }^{25}$ See in particular McMahan, Killing in War.
} 
and statist views that it replaces. One wonders what the point of a radical theoretical challenge is, if it is not going to lead to radical practical conclusions. There is an interesting contrast with revisionism in another area of international morality, concerning global distributive justice. In that field, there are similarly radical theoretical critiques, which seek to show how the current statist international order is inconsistent with defensible principles of interpersonal morality, but these theoretical critiques invariably lead to practical critiques as well. ${ }^{26}$ One does not often find a cosmopolitan about global justice who believes that the dominant common-sense view about what human beings owe to one another qua human beings has a clean bill of health.

If we are to insist on the standard form of reductionism, then, I think we had better accept the bloodless invasion objection's conclusion that warfare against purely political aggression is unjustified, but insist that, in this clash between theory and intuition, theory should win out. However, if we insist on defending a more conservative reductionism, we could proceed by denying either of the two descriptive claims, in premises 5 and 6 . I have already discussed 5 in enough depth for our present purposes. The real action is in denying premise $6 .^{27}$

The denial of premise 6 takes two different forms. Each concedes that a purely political aggression is conceptually possible, but one form of the response is more empirically contingent than the other. The more contingent response simply asserts that, as a matter of historical fact, there has never been a bloodless invasion, and as such the difficulty of justifying the resort to force to avert one should be of no concern, since we can infer from the historical record that purely political aggressions will never occur. The bloodless invasion objection is thereby dismissed as a purely theoretical worry.

The second response runs like this: in any invasion that might otherwise appear to satisfy premise 6 , the threat to the defenders' purely political interests at time $\mathrm{T}_{\mathrm{o}}$ will in fact be backed up with a threat to attack their vital interests at $T_{2}$, should the defenders seek at $\mathrm{T}_{1}$ to avert the initial political threat. In virtue of this subsequent $\mathrm{T}_{2}$ threat to their vital interests, the defenders can justify using lethal force at $\mathrm{T}_{1}$-although it would be disproportionate to avert the $\mathrm{T}_{\mathrm{o}}$ threat, it is proportionate (and can be justified as a lesser evil) when the $\mathrm{T}_{2}$ threat is taken into account. I discuss each response in turn.

The first counterargument infers from the claim that history has seen few if any bloodless invasions the conclusion that premise 8 is misguided-justifying defence against purely political aggression is not a plausible desideratum on theories of the ethics of war. However, this obviously presupposes a further premise, namely that whether 8 holds depends on whether there have been any actual cases of purely political aggression. This requires substantiation, and is prima facie wrong: even if no bloodless invasions had

\footnotetext{
${ }^{26}$ See, for example, Simon Caney, Justice Beyond Borders: A Global Political Theory (Oxford: Oxford University Press, 2005); Thomas Pogge, World Poverty and Human Rights: Cosmopolitan Responsibilities and Reforms (Cambridge: Polity Press, 2002).

${ }_{27}$ To recall: ' 6 . There are some purely political wars, in which the aggressors threaten only the victims' interests in their state's continued political control of some territory-their purely political interests'.
} 
ever occurred, and none were ever likely, the objection would still stand if we could conceive of a bloodless invasion, and believe that resistance against it would be justified. The empirical counterargument is orthogonal to the central problem here. Interestingly, it also sits extremely ill with other elements of the standard reductionist account, which is typically constructed out of hypothetical cases with little or no practical application. ${ }^{28}$

However, while I think that few reductionists are well placed to raise this empirical counterargument to the bloodless invasion objection, and that even if bloodless invasions were purely hypothetical possibilities the objection would survive, the objection would undoubtedly have more purchase, and premise 8 would be more plausible, if we could demonstrate it had practical application.

Seeking firmer empirical foundations for the bloodless invasion objection, however, is complicated by two problems. First, the interpretation of historical events such as armed conflicts is likely to be even more contentious and contested than our arguments for normative principles to govern war. Second, a compendious knowledge of historical events is not sufficient to establish whether history offers cases of purely political aggression, because we need to know not only what actually happened, but what would have happened had the invaded state not resisted. As we seek arguably unnecessary empirical substantiation for the bloodless invasion objection, then, we must remember that we have moved squarely into the sphere of speculation, which must be treated as merely heuristic.

With these caveats in mind, I venture that the problem of purely political aggression is not merely hypothetical. Consider, for example, the recent wars fought by the United States and its allies. Their goals are often purely political-they aim to replace an unfriendly government, impose a set of institutions, or secure control over resources. Even when their aims exceed these, they remain tightly constrained-for example, to pursue a small group of people responsible for a terrorist attack. They use force with regret, and kill only as a means to their goals. If our adversaries would simply submit and concede, no blood, or at least very little, will be shed. Of course, in practice quite the opposite has occurred-nobody would call the invasion of Iraq or Afghanistan, or the bombing of Libya, bloodless. Evidently, however, our assaults on those countries were met with violent resistance, so the option of non-violent conquest was clearly off the table. It is at least reasonable to believe that, if our troops had met with surrender and submission, we would have confined ourselves to securing our purely political objectives. For example, the Rules of Engagement apparently operational for British forces in Iraq in 2006 (according to a leaked document, available from Wikileaks) state the following general principles governing the use of force:

3.1. The use of lethal force is permitted only to prevent loss of life or to protect materiel, the loss or destruction of which could be potentially life threatening for Coalition Forces.

\footnotetext{
${ }^{28}$ A complaint made, for example, by Walzer in 'Response to McMahan's Paper', Philosophia, 34/1 (2006), $43-5: 34$.
} 
3.2 Force should be used as a last resort only. Whenever feasible other means of escalation control should be applied. E.g. verbal warnings and/or show of force.

3.3 The degree of force used must be no more than is reasonably necessary to control the situation. In all cases the utmost care must be taken to avoid harm to civilians or damage to civilian property. ${ }^{29}$

It is quite conceivable that a state's armed forces could adhere to rules of engagement like these, while engaged in a purely political aggression, so long as they met with no resistance. Moreover, when testing the implications of an account of the ethics of war, we should consider not only the actual historical record and the current political climate; we should also ask what would happen if this account were widely endorsed. And it seems that if the standard reductionist view were widely acknowledged, then purely political aggressions would become far more common, since expansionist governments would know that the invaded could not justifiably resist them. We might then reasonably expect states like Russia and China, which have long-simmering territorial disputes with their neighbours, to take advantage of the opportunity to settle those disputes through bloodless invasion.

A mere appeal to history, then, is inadequate. If we want to save standard reductionism, we had better argue that any likely form of purely political aggression will in fact be backed up with threats to vital interests, in virtue of which using lethal force can be proportionate.

The most promising response to the argument from political aggression focuses on the predictability that the aggressor will come to pose some threat to the defenders' vital interests in future, even if at present only lesser interests are at stake. ${ }^{30}$ There are two plausible approaches. The first simply notes that, since the aggressors will pose a lethal threat to the defenders if the latter resist, the defenders now face an imminent threat of unjustified harm to their vital interests, such as can render self-defence and collateral killing proportionate. The second observes that, even if the defenders now refrain from using force to defend themselves, by allowing this purely political aggression to succeed, they leave themselves vulnerable to future harms to their vital interests. $^{31}$

Both of these responses argue that defenders may permissibly use lethal force now, to avert a threat to their vital interests that is not now imminent. In the standard terminology, they are arguments for preventive, not pre-emptive defence. Although imminence of the threat has sometimes been thought one of the necessary conditions for liability, most now agree that it is no more than a useful proxy to overcome uncertainty over whether a threat will eventuate, and whether using lethal force is a necessary

\footnotetext{
${ }^{29}$ UK Ministry Of Defence, 'UK and Danish Rules of Engagement for Iraq', Wikileaks http://wikileaks.org/ wiki/UK_and_Danish_Rules_of_Engagement_for_Iraq_2006 (accessed 26 July 2013).

${ }^{30}$ Hurka, 'Proportionality', 54-5; McMahan, 'Innocence', 196; McMahan, 'War as Self-Defence', 78.

${ }^{31}$ McMahan and Fabre, in this volume, make both arguments.
} 
response. ${ }^{32}$ If the unjustified threat is imminent, then we can be more confident that it will eventuate, and that lethal force is necessary. But if imminence is a proxy for sufficiently justified belief, then we can have such a belief when the threat is further downstream.

Of the two appeals to preventive defence, the first is stronger than the second. That the aggressors will fight back if we resist is a given in all actual cases-although not in hypothetically conceivable ones, which remains a problem. The possibility of subsequent unjustified threats emerging, however, is much more contingent and speculative. Moreover, recall that it is harder to justify using lethal force now, the weaker our targets' responsibility for, and so contribution to the unjustified threats that we seek to avert. The further downstream the relevant threats, the less plausible it is to hold our immediate targets responsible for them, and so liable to be killed in self-defence to avert them.

We should concentrate, then, on the first version of this second counterargument to the bloodless invasion objection. ${ }^{33}$ It is usually illustrated with a counterexample. Suppose you are accosted by a mugger, who demands your money or your life. You cannot prevent him from taking your money, except by killing him. It seems that lethal defence would be disproportionate in this case.

However, if you were to attempt a proportionate response, such as pushing him away, he would then act on his initial threat, and kill you. This suggests that you do, in fact, face an unjustified threat to your vital interests, which can render killing the mugger proportionate. In other words, at $\mathrm{T}_{0}$ the mugger poses a threat only to your wallet. If you try to defend yourself proportionately in response to that threat at $\mathrm{T}_{1}$, then at $\mathrm{T}_{2}$ he will try to kill you. ${ }^{34}$ If you could kill him in self-defence at $\mathrm{T}_{3}$, in response to the $\mathrm{T}_{2}$ threat, then why must you wait until $\mathrm{T}_{3}$ to do so? After all, you know at $\mathrm{T}_{\mathrm{o}}$ what he will do at $\mathrm{T}_{2}$. Moreover, suppose that if you wait until $\mathrm{T}_{3}$ to defend yourself against the $\mathrm{T}_{2}$ threat, your prospects of averting it diminish. One might plausibly argue that it is permissible to defend yourself with lethal force at $\mathrm{T}_{1}$ in order to avert the unjustified threat to your vital interests at $\mathrm{T}_{2}$, even though the initial threat at $\mathrm{T}_{\mathrm{o}}$ is only to your lesser interests. The relevant proportionality calculation is with the $\mathrm{T}_{2}$ threat to your vital interests, not the initial $\mathrm{T}$ threat to your lesser interests.

It is easy to see how this argument would be applied to the context of war. When at $T_{\text {o }}$ the adversary combatants invade, they threaten only our political interests. If we should attempt a proportionate response at $\mathrm{T}_{1}$, however, they would fight back, threatening

\footnotetext{
${ }^{32}$ See e.g. David Luban, 'Preventive War', Philosophy \& Public Affairs, 32/3 (2004), 207-48; Suzanne Uniacke, 'On Getting One's Retaliation in First', in Henry Shue and David Rodin (eds.), Preemption: Military Action and Moral Justification (Oxford: Oxford University Press, 2007), 69-88.

${ }^{33}$ Although see McMahan, chapter 6 in this volume, for a more sympathetic view of the second line.

${ }^{34}$ The points in time are differentiated to show that defender's action at $\mathrm{T}_{1}$ is a response to the $\mathrm{T}_{0}$ threat, and prevents the $\mathrm{T}_{2}$ threat from coming about. The $\mathrm{T}_{2}$ threat is likewise a response to defender's action at $\mathrm{T}_{1}$. When I write that the attacker poses a threat at $\mathrm{T}_{0}{ }_{0}^{2}$ this does not mean the threat will eventuate at $\mathrm{T}_{0}-\mathrm{it}$ will eventuate imminently, if the defender does nothing, but by defending himself at $\mathrm{T}_{1}$ he could prevent the threat being realized.
} 
our vital interests at $\mathrm{T}_{2}$. We should, at $\mathrm{T}_{0}$, be allowed to use the $\mathrm{T}_{2}$ threat posed by our adversaries in the calculation of proportionality. Because we are certain that the $\mathrm{T}_{2}$ threat will eventuate, we do not need to wait until $\mathrm{T}_{3}$, when the threat is already in train and our chances of averting it might have been diminished. Although advocates of this argument have not said so explicitly, it extends quite naturally over to the justification of collateral killing. When determining proportionality in collateral harm, the relevant threat is not the $\mathrm{T}_{\mathrm{o}}$ threat to our political interests, but the $\mathrm{T}_{2}$ threat to our vital ones.

This counterargument does not resolve the bloodless invasion objection at the level of principle-it is easy to conceive of a purely political aggressor that resolves not to fight back if we resist, in a form of non-violent political aggression. However, if it went through, it would seriously mitigate the objection's practical implications. Unfortunately for standard reductionism, however, I think it begs the question against the more plausible form of this objection.

We must first distinguish between two forms of conditional threat that the aggressor can pose. The aggressor might directly threaten the victim, so that she knows that if she resists, she will be killed. Or the aggressor might simply resolve to defend himself, should the victim use the threat of lethal force against him. In the first case, the aggressor's threat is conditioned on the victim's resisting in any way; in the second, the aggressor does not literally 'threaten' the victim, but instead will use lethal force, if he has to, to defend himself. The first, coercive model is where the thief says 'your money or your life'; the second, defensive model is where the thief simply takes your money, and defends himself if you try to use force to stop him doing so.

Although some of my arguments apply to the coercive model, I'm going to focus on the second, purely defensive model, which is I think most apt for the problem of purely political aggression. Lethal defence against an aggressor that rolls over the border, promising to kill anyone who resists, is probably justifiable in individualist terms, either on grounds of the attempt at coercion that it involves, or on the likelihood of future threats to vital interests (an aggressor prepared to issue a threat to kill all who resist is unlikely not to act on that threat). ${ }^{35}$ The second model is also important, however. It is quite conceivable that a purely political aggressor should seek to achieve its political objectives not through direct coercion, but by establishing facts on the ground that give them control of the decisive resources or institutions. They could advance towards their goals without issuing any threats to the aggressed-against populace, but simply make it known that they will use force in defence of their lives and their mission, when it is necessary to do so, and against those who pose such threats. Indeed, these principles are similar to the rules of engagement by which British soldiers in Iraq were supposed to abide. ${ }^{36}$ In this case, the aggressors are similar to the thief who resolves to take the victim's wallet by force, but does not issue the threat

\footnotetext{
${ }_{35}$ Although see Rodin, chapter 4 in this volume, for an argument that works against even these cases of coercive conditional threats.

${ }^{36}$ See MoD, 'UK and Danish Rules of Engagement for Iraq'.
} 
'your money or your life', instead only using force to defend himself against the victim's resistance.

In these cases, where the aggressor uses force only in self-defence, his actions at $\mathrm{T}_{2}$ are a response to the victim's actions at $\mathrm{T}_{1}$. If the victim's actions at $\mathrm{T}_{1}$ were impermissible, then the victim could obviously not use the threat she would face at $\mathrm{T}_{2}$ in her proportionality calculations at $\mathrm{T}_{\mathrm{o}}$. Suppose, for example, that at $\mathrm{T}_{\mathrm{o}}$ the mugger does not intend to kill the victim. The victim, however, responds to this threat wildly disproportionately at $\mathrm{T}_{1}$, making to throw a grenade at the mugger, who (suppose) is surrounded by children, who will be killed alongside him. At $\mathrm{T}_{2}$, the mugger will try to prevent the victim throwing that grenade, by shooting him. Clearly, in this case the victim cannot use the threat he will face at $\mathrm{T}_{2}$ in his proportionality calculations at $\mathrm{T}_{0}$. In general, the appeal to preventive defence must presuppose that any relevant actions taken by the victim between now and when the threat eventuates should be permissible.

Or consider this example. A is insulting B. He ought not to do so, but he clearly does not threaten a serious interest of hers. B knows that if she tries to prevent $\mathrm{A}$ insulting her by using lethal force against him, he will try to kill her. So, can she conclude that since A will try to kill her if she uses lethal force to stop him insulting her, it is proportionate for her to use lethal force, before he has the chance to do so? Clearly she cannot. Lethal force is not a proportionate means to stop someone insulting you, and it cannot be rendered proportionate by the fact that, if you attempt to use lethal force, the insulter will try to defend himself lethally.

It follows that the argument from preventive defence begs the question, at least when the attacker's lethal threat is conditioned on the defender first threatening his life (in other words, when the attacker will use force only in self-defence). If the mugger resolves to use force at $\mathrm{T}_{2}$ only to defend himself against a lethal threat at $\mathrm{T}_{1}$, then we cannot argue that lethal defence by the victim at $\mathrm{T}_{1}$ is proportionate, without presupposing that it is justified-which is precisely what we are trying to show. The threat posed by mugger at $\mathrm{T}_{2}$ is admissible in the $\mathrm{T}_{\mathrm{o}}$ proportionality calculation only if the victim's actions at $\mathrm{T}_{1}$ are justified; the victim's actions at $\mathrm{T}_{1}$ are justified only if the threat posed by the mugger at $\mathrm{T}_{2}$ is admissible in the $\mathrm{T}_{0}$ proportionality calculation. Applied to the military context, provided the purely political aggressors resolve to use force at $\mathrm{T}_{2}$ only in response to lethal threats at $\mathrm{T}_{1}$, then we cannot argue that this lethal response by the victims is proportionate except by assuming that it is justified.

Notice that the argument does not depend on showing that the victim's response to the initial threat is disproportionate. These examples are merely illustrations of a more general logical point. A cannot without circularity at $\mathrm{T}_{\mathrm{o}}$ justify using lethal force at $\mathrm{T}_{1}$ to prevent a threat, to be posed by $\mathrm{B}$ at $\mathrm{T}_{2}$, which is conditioned on A's using lethal force at $\mathrm{T}_{1}$. A's use of lethal force at $\mathrm{T}_{1}$ is permissible only if B's threat at $\mathrm{T}_{2}$ renders lethal force proportionate in the $\mathrm{T}_{0}$ proportionality calculation. But B's threat at $\mathrm{T}_{2}$ is admissible in A's justification at $\mathrm{T}_{0}$ only if A's action at $\mathrm{T}_{1}$ is permissible. The preventive defence-based response to the bloodless invasion objection therefore works only if it 
assumes that lethal defence against purely political aggression is justified, which is precisely what it is supposed to prove.

How might a reductionist respond to this circularity objection? One might argue that, provided we know that B's threat at $\mathrm{T}_{2}$ will be unjustified regardless of A's intervening actions, the justification from preventive defence is admissible, and A can use the $\mathrm{T}_{2}$ threat in his $\mathrm{T}_{\mathrm{o}}$ proportionality calculations. What matters is not the chain of events that leads to the threat at $\mathrm{T}_{2}$, but simply whether that threat is unjustified.

The circularity objection is particularly forceful when the justification of the $T_{2}$ threat depends on the justification of the defender's actions at $\mathrm{T}_{1}$. Suppose, for example, that the combatants fighting for the purely political aggressor are publicly resolved to use force only in defence of their lives, when it is necessary to do so, and against those who are responsible for posing those threats. One ground on which the threat they pose at $\mathrm{T}_{2}$ could be unjustified, then, is that the threat to which they respond is itself justified. But the argument from preventive defence justifies lethal defence at $T_{1}$ by assuming $\left(\right.$ at $\mathrm{T}_{\mathrm{o}}$ ) that the threat posed by the aggressor at $\mathrm{T}_{2}$ will be unjustified. To show that the $\mathrm{T}_{2}$ threat is unjustified, we must show that the $\mathrm{T}_{1}$ threat is justified; but to show that the $\mathrm{T}_{1}$ threat is justified, we must assume that the $\mathrm{T}_{2}$ threat is unjustified.

However, there are other reasons besides the fact that it responds to an unjustified threat which can make the $\mathrm{T}_{2}$ threat unjustified. If these are in play, then does the circularity objection still apply? One could argue that any use of force by a purely political aggressor, even in self-defence, can be justified only if it is in some sense necessary (the precise interpretation of necessity does not matter here). ${ }^{37}$ Since purely political aggressors could defend themselves by retreating, thereby foregoing their military objectives, any force they use in self-defence is unnecessary, and therefore impermissible on those grounds alone, irrespective of whether the defenders' actions at $\mathrm{T}_{1}$ are justified, so there is no circularity problem.

One way to respond would be to question whether the aggressors really could not satisfy necessity. Whatever our theory of necessity, it seems misguided to imply that purely political aggressors could simply down arms and pull out. This may be true of them en masse, but for each individual soldier, retreat or surrender is often likely to increase, not diminish, his chances of being harmed. Using force to defend himself and his comrades may well be his only way to get out alive. So, the counterargument has limited scope. Nonetheless, it will apply in some cases, so deserves a response.

I think it fails as a response to the circularity objection. If a threat posed by B at $\mathrm{T}_{2}$ will eventuate only if $\mathrm{A}$ acts unjustifiably at $\mathrm{T}_{1}$, then even if that future threat will be unjustified on independent grounds, it remains inadmissible in A's proportionality calculation at $\mathrm{T}_{\mathrm{o}}$, because it is conditioned on his intervening wrongful action at $\mathrm{T}_{1}$. If that action is wrongful, he ought not to do it, and the $\mathrm{T}_{2}$ threat will not eventuate. He may not harm another now to avert a threat that will come about only if he acts

${ }^{37}$ Although for a sustained analysis, see Seth Lazar, 'Necessity in Self-Defense and War', Philosophy \& Public Affairs, 40/1, (2012) 3-43. 
unjustifiably. It follows that if B's $\mathrm{T}_{2}$ threat is conditioned on A's use of lethal force at $\mathrm{T}_{1}$, A cannot appeal to the $\mathrm{T}_{2}$ threat posed by $\mathrm{B}$ in his $\mathrm{T}_{\mathrm{o}}$ proportionality calculation without assuming that his use of lethal force at $\mathrm{T}_{1}$ is justified, and so begging the question that the argument is supposed to answer. Notice that this reasoning applies as much to the coercive as to the defensive version of the conditional threat case. B's reasons for harming $\mathrm{A}$ at $\mathrm{T}_{2}$ can be either in self-defence, or in order to make good on her initial threat to A.

In summary, then, the argument from preventive defence can presuppose its conclusion in two ways. First, by assuming the threat posed by the aggressor at $\mathrm{T}_{2}$ is unjustified, when whether that is true depends on whether the $\mathrm{T}_{1}$ threat is justified. This will not always apply-sometimes there will be independent grounds for believing the $\mathrm{T}_{2}$ threat unjustified, regardless of whether the $\mathrm{T}_{1}$ threat is justified. However, the second circularity is not contingent in this way. The $\mathrm{T}_{2}$ threat is inadmissible to the $\mathrm{T}_{\mathrm{o}}$ proportionality calculation if it is a response to unjustified action by $\mathrm{A}$ at $\mathrm{T}_{1}$. To include the $\mathrm{T}_{2}$ threat in A's $\mathrm{T}_{0}$ proportionality calculation, then, is to assume that A's action at $\mathrm{T}_{1}$ is justified. But it is precisely that action (on which B's response is conditioned) that the argument is supposed to justify. On this argument, we can justify A's $\mathrm{T}_{\mathrm{o}}$ response only by assuming that it is justified. This second circularity is present even when we have independent grounds to believe the $\mathrm{T}_{2}$ threat will be unjustified.

Might one nonetheless counter that it is strange that the mugger can, merely by making his conditional threat, leave you no other morally acceptable option but to capitulate $?^{38}$ Although this does not address the circularity problem, it might indicate that we need to rethink it. However, this does not seem a compelling response. There are many ways besides through making a conditional threat that a mugger can leave his victim with no morally acceptable alternative besides capitulation - he could position himself so that there is no way for the victim to defend herself without inflicting disproportionate harm on bystanders; or, if he is strong enough, he could make it so she has no way to protect her wallet except to kill him; alternatively, the same situation arises if he is so frail that any resistance would kill him. In each case, assuming it is disproportionate to kill just to retain her wallet, the victim has no choice but to yield. Nor should this surprise us. Principles of self-defence constrain otherwise justified defence in ways that an unscrupulous attacker can manipulate. The only way to avoid this outcome is either to deny that those principles should be genuine constraints, or to argue that using lethal force to retain one's wallet is in fact proportionate.

The circularity objection could be escaped if we could provide grounds for the victim's initial defence being justified, which do not depend on including the conditional threat (CT) that is conditioned on that defence in the argument for its justification. ${ }^{39}$ One might think, however, that this counterargument is a non-starter. Insofar as the

${ }^{38}$ McMahan, 'War as Self-Defence', 78. Hurka makes a very similar point at Hurka, 'Proportionality', 54.

${ }_{39}$ Thanks to Cécile Fabre for helping me think this through. 
eventuation of CT is a foreseeable consequence of the victim's defensive actions, it must be included in our assessment of those actions' proportionality. If the threat is great enough, then perhaps any defensive action would be disproportionate. ${ }^{40}$ For the sake of argument, however, let us set that worry aside, and suppose that we could, in principle, establish that the victim's initial defence is justified without CT telling either for or against that defence.

Here is one possibility. Even if lethal defence is disproportionate, presumably (if CT is set to one side) some use of force by the victim to avert the initial threat (IT) posed at $\mathrm{T}_{\mathrm{o}}$ by the aggressor would be proportionate. Suppose that if the victim were to protect herself against IT using proportionate force (call this PF), the aggressor would use some additional force (call this AF) to secure his objectives. In that case, the victim can presumably use the latter quantum of threat $(\mathrm{IT}+\mathrm{AF})$ in her initial proportionality calculations, thus increasing the amount of force that would be proportionate, than if it were only a matter of averting IT-call it $\mathrm{PF}^{\star}$. There is no circularity yet, because $\mathrm{PF}$ is justified without reference to CT. But suppose that if the victim uses $\mathrm{PF}^{\star}$ force, the aggressor will respond with more additional force- $\mathrm{AF}^{*}$. Then the victim would be able to use force proportionate to $\left(\mathrm{IT}+\mathrm{AF}^{\star}\right)$, i.e. more than $\mathrm{PF}^{\star}$, say $\mathrm{PF}^{\star \star}$. If our reasoning proceeds incrementally in this way, we could reach a situation where it is proportionate for the victim to use lethal force to defend herself, not because of the conditional threat $\mathrm{CT}$, but because of the additional force $\mathrm{AF}^{\star * \star}$ which the aggressor would use in order to achieve the initial threat IT should the victim use $\mathrm{PF}^{* * *}$ force to defend herself.

In the mugger example, the idea is something like this. Though it's disproportionate for the victim to just kill the mugger outright, suppose she uses proportionate forceshe pushes him back. Suppose he would respond by using more initial force against here; can we not then say that she is permitted to use defensive force proportionate to this additional threat? We might then proceed incrementally to the justification of victim using lethal defensive force, without any circularity. In the military case, suppose we respond to the purely political aggression by forming a human chain around the aggressor's targets, so that they cannot secure them except by threatening our lives. In that case, we would be entitled to kill them in self-defence. So why should we have to actually put ourselves at risk by forming the human chain? Why not proceed immediately to the lethal defence?

Although I think that this incrementalist response has some virtues (albeit that simplicity is not one of them) it ultimately fails. Intuitively, it fails because it proves too much. Suppose that the initial threat posed by the aggressor is that he is going to pinch the victim. But suppose that he will defend himself and his mission (to pinch her) against any force the victim uses in her defence. So the victim responds proportionately, by trying to pinch him first (this is PF). The aggressor averts that pinch by

\footnotetext{
${ }^{40}$ This is one of David Rodin's key arguments in chapter 4 of this volume.
} 
making to pinch and also punch the victim. That's the initial threat IT and the additional force AF. This larger threat renders a graver defence by the victim proportionate $-\mathrm{PF}^{*}$. But that additional force used by the victim leads to the aggressor using still more additional force- $\mathrm{AF}^{*}$, which in turn renders a still graver defence by the victim proportionate $-\mathrm{PF}^{* *}$. And in this incremental way we can reach a situation where the only way to stop the aggressor pinching her (and inflicting the additional force $\mathrm{AF}^{\star * \star}$ on her) is to kill him. If this response to the circularity objection works, then it is proportionate for the victim to kill the aggressor, ultimately, to prevent him from pinching her.

The second problem with the incrementalist response is more internal. It rests on a very specific and involuted series of counterfactuals. This is how it achieves the bootstrapping whereby the threat of a pinch can become grounds for killing someone. The argument depends on saying that 'if I were to X, then you'd Y, but if you would Y, then I could X1, but if I X1'd, then you would $Y_{1}$, and if you would $Y_{1}$, I could X2,' and so on to the nth and n-1th value of X and $\mathrm{Y}$. This leads to at least two problems.

First, we can legitimately question whether the permission to use lethal force can depend on speculation about such complex counterfactuals. Arguably rather than simply rest on assumptions about what would happen if we took all these intermediate steps, we actually ought to take those steps. Rather than say 'we're entitled to use lethal force now, because if we resisted non-violently, they would use greater force, which would entitle us to use greater force, which would lead to greater force from them, which would entitle us to use greater force, ultimately leading to us being entitled to use lethal force', this incrementalist argument looks like it enjoins us to actually take those intermediate steps. In practice this would mean first resisting political aggression non-violently, and using lethal force only once the aggressor has started to threaten our vital interests.

Second, there is an important range of cases where the counterfactual story required for the incrementalist response to work will simply not obtain. The incrementalist response fails just in case there is no way for the victim to avert the initial threat except by using lethal force against the aggressor. In the mugger example, suppose that the mugger is much stronger than the victim, and simply immobilizes her while he takes her wallet. Her only means of protecting the wallet is to kill him. Or that he takes her wallet and runs off-she can bring him down only by shooting him. In a military context, suppose that the aggressor establishes facts on the ground that can be changed only by using lethal force. In each of these cases the incrementalist response fails. The only way to avert the initial threat is to kill the aggressor; this is by hypothesis a disproportionate means of averting that initial threat; and the prospect of the aggressor defending himself with lethal force against the victim's attempt to kill him cannot be used to render that attempt proportionate without circularity. 


\subsection{Alternative Reductionisms}

Neither the contingent empirical counterargument, nor the conceptual challenge from preventive defence, succeeds in undermining premise 6 . If we endorse the other descriptive and evaluative premises 5,7 , and 8 , then we must either endorse the conclusion, and reject reductionism, or we must show how by modifying premises 2, 3, or 4, we can develop a version of reductionism that can ground the permission to fight defensive wars against purely political aggression-what Emerton and Handfield call the 'political defensive privilege. ${ }^{41}$ In this section and the next, I consider three ways to ground the political defensive privilege, each of which does more violence to standard reductionism than the last. The first merely modifies premises 3 and 4 , the second proposes an alternative to premise 2, while the third, discussed in section 2.5, rejects reductionism in favour of exceptionalism.

One way a reductionist might ground the political defensive privilege is by modifying, or at least adding to, premises 3 and 4 . After all, they specify only a narrow range of the relevant principles of interpersonal morality. Perhaps they leave something out that might help here. Although when defending oneself, or a small number of others, vital interests must be at stake for killing the innocent either intentionally or collaterally to be justified, perhaps if enough people's lesser interests are at stake, they can together justify lethal force. The problem of proportionality in self-defence and collateral damage is overcome, on this view, by aggregating the lesser interests of the invaded state's citizens. ${ }^{42}$

Although the move to aggregation is popular among reductionists, it is not a promising response to the bloodless invasion objection, for at least three reasons, of which at least the third is decisive.

First, aggregation cuts both ways: although the victims of a purely political aggression are numerous, the innocent victims of war (on both sides) will be numerous too. I am not sure whether these two aggregations will cancel each other out, and indeed I wonder whether we can confidently weigh such numerous and disparate interests.

Second, I wonder whether this move to aggregation is consistent with the core thesis of reductionism. I cannot think of any other cases, outside of war, where the same phenomenon would apply - where a large number of aggregated lesser interests can justify killing innocent people in self-defence and collateral harm. It seems, then, that war is indeed morally exceptional, since the principles that justify killing in war do not justify any other acts besides those of war.

Third, and most importantly, though, aggregation of lesser interests is simply an implausible foundation for the political defensive privilege, because it entails that the scope and weight of that privilege will vary in proportion to a political community's

\footnotetext{
${ }^{41}$ Emerton and Handfield, chapter 3 in this volume.

${ }^{42}$ Hurka, 'Proportionality', 54; McMahan, 'War as Self-Defence', 79. See also Fabre, chapter 5 in this volume.
} 
population size. The more citizens, the more people whose lesser interest in their state retaining political control of a territory is at stake. The more people, the greater the aggregated sum of their lesser political interests. The greater that sum, the easier it is for them to justify resorting to force against a purely political aggression, and the more innocent people they can justify killing to defend their political independence. So, in a war over territory between Pakistan and India, the latter would be entitled to kill more Pakistanis than Pakistanis could kill Indians, because 1.2bn Indian citizens purportedly have an interest in control of that territory, while only 0.2bn Pakistanis have the same interest. And yet clearly if we endorse something like the political defensive privilege, we ascribe it equally to states regardless of their population size. While there might be grounds for questioning the international legal doctrine of sovereign equality-some states are presumably insufficiently valuable to warrant defence-mere differences in population size are surely morally irrelevant.

One could perhaps respond by arguing that political interests have diminishing marginal moral importance, such that once you have a country with a certain population, any additional citizens do not increase the moral importance of the political interests at stake. However, this would be a significant move away from the individualist approach, since it presupposes that the moral weight of an individual's interests is a function of how large a group of similarly interested individuals he is in. This looks like an argument for war in defence of irreducibly collective rights, not a thoroughgoing individualist account.

Merely shifting the focus to aggregation, then, is not enough. Reductionists remain incapable of grounding the political defensive privilege. Their next available move is more radical, but perhaps more promising. It involves rejecting not only premises 3 and 4 , but premise 2 as well-in other words, it proposes a non-standard form of reductionism. Perhaps if we look to other principles of ordinary interpersonal morality besides those covering self-defence and collateral harm, we can develop a basis for the political defensive privilege.

Standard reductionism, as formulated in the bloodless invasion objection, is clearly correlated with a nonconsequentialist view of morality, which sees people as enjoying fundamental protections against being used and harmed in various ways, even if harming them would realize a more valuable state of affairs. ${ }^{43}$ Perhaps reductionists would do better to adopt a consequentialist view of the ordinary interpersonal morality governing permissible killing. They might endorse either act or rule consequentialism, while remaining reductionists about the ethics of war-since they would argue that in war as in ordinary life, we should follow the maxim 'act so as to realize the most valuable state of affairs', or 'act in accordance with the rule that, in the long run, realizes the most valuable state of affairs'

${ }^{43}$ See e.g. Frances M. Kamm, 'Nonconsequentialism', in Hugh Lafollette (ed.), The Blackwell Guide to Ethical Theory (Malden: Blackwell, 2001), 205-26; Warren S. Quinn, 'Actions, Intentions, and Consequences: The Doctrine of Double Effect', Philosophy and Public Affairs, 18/4 (1989), 334-51. 
In theory, shifting to a consequentialist position should lower the bar to justify killing. However, I think premises 3 and 4 genuinely specify the most permissive plausible take on when killing is allowed, whether one is a consequentialist or a nonconsequentialist: killing the innocent to preserve less than vital interests is simply never going to be justified. We have already seen that moving to aggregation does not help resolve this problem. If consequentialist reductionists are going to fare any better than the nonconsequentialist, they have to identify some other values besides individuals' interests that are worth fighting for. If they concede that individuals' purely political interests are not that important, they must argue one of the following: that there are distinct collective interests in the political independence of a particular community, which can justify killing; that there is some impersonal value in the continued independence of a political community; or that there are some broader long-term values that must be brought into our calculation. I doubt whether any of these moves is genuinely consistent with the reductionist perspective-although the consequentialist pays lip service to reductionism, the values that are at stake in war include some that are quite different from the values at stake when force is used in ordinary life.

Moreover, it is far from clear that an act-consequentialist approach to the ethics of war would end up grounding a political defensive privilege. Certainly, it would depend on the particular case; choosing to resist a purely political aggression with force involves realizing a state of affairs in which each side inflicts suffering and devastation on the other. The alternative involves sacrificing only the purely political interests of the citizens of the invaded state. It is hard to imagine that war would not constitute a worse state of affairs, such that the act-consequentialist would deny states the privilege to defend themselves.

A rule-consequentialist might fare better here. The rule-consequentialist could argue that, if we do not resist purely political aggression now, it will become widespread, and lead to even more numerous and greater harms than would fighting now. ${ }^{44}$ For example, one might argue that in order to have a stable system of relations among states, which is in turn necessary for people to live good lives, we need something like a principle of respect for political independence. Since there is no other means to enforce this principle except through self-help, states must be entitled to defend themselves against purely political aggression. The defenders are fighting not only for their own purely political interests, but for the purely political interests of all people everywhere, who are all made more vulnerable each time a purely political aggressor claims territory unchallenged.

There is probably considerable mileage in this argument, although it does involve making some very substantial theoretical commitments, which might have more troubling implications when set in other contexts. Ultimately, though, I do not think it can plausibly be described as reductionist, except in the thinnest sense. If what justifies

\footnotetext{
${ }^{44}$ See McMahan, chapter 6, and Moore, chapter 8 in this volume.
} 
killing the innocent in war is the importance of preventing future purely political aggressions (as well as this one) then we are definitely far from the realm of ordinary interpersonal morality; the justification for these acts of killing cannot be understood without acknowledging that they are acts of killing in war, not ordinary life. Justified wars fought for these reasons will not simply be justified acts of self- and other-defence. They will also be justified by their contribution to maintaining a stable international system.

\subsection{Desiderata for an Exceptionalist Alternative}

If we are going to give a plausible account of what is worth fighting for in wars of national defence generally, and wars against purely political aggression in particular, then it looks like we need to reject reductionism. The goods that it is worth killing for in ordinary life simply are not sufficient to explain the permissibility of killing in war. The challenge, then, is to develop a plausible exceptionalist account of what is worth fighting for, which can fill the gap identified by the bloodless invasion objection, without inviting further unanswerable objections. Evidently, I cannot attempt that task in what remains of this chapter; however, I can identify some desiderata on what such an account should look like, specifically three positive requirements, and two negative ones.

The bloodless invasion objection shows that the individual interests immediately at stake in a war of purely political aggression are not sufficiently weighty to justify killing the innocent. If killing the innocent is nonetheless justified, then either there must be other individual interests that a simple description of the case has missed, or there must be other goods besides individual interests that are at stake. The first positive requirement on an exceptionalist account of what justifies wars of national defence is that it must identify the goods, beyond the immediately threatened individual interests, which justify fighting. There are three plausible avenues (which need not be mutually exclusive).

As we have just seen, the first, and least controversial, is to appeal not only to the immediately implicated individual interests, but also to the long-term interests of all people. This is the (in spirit) rule-consequentialist argument that submission to aggression now, even if it is purely political, will invite future harms, to avert which we are justified in killing the innocent now, as a lesser evil. Speculative though it is, this argument is undoubtedly an important constituent in the justification of wars of national defence in general, although it does not, to my mind, capture the full force of what is worth fighting for in defence against purely political aggression in particular. After all, if the aggressor's success in this bloodless invasion were only to lead to more purely political aggression in future, then the interests at stake in the future will be precisely the same ones as do not justify killing the innocent when the present case is taken in isolation. Of course, by looking to the future we increase the number of people whose political interests are potentially at stake, but we have seen that grounding the 
permission to kill in individuals' aggregated purely political interests leads to deeply implausible implications about what can permissibly be done to defend more and less populous political communities.

For these reasons, I think the most interesting alternatives to the reduction of warfare to self- and other-defence will not only invoke other individual interests besides those immediately at stake, but will look to collective and impersonal goods to explain what justifies fighting. Impersonal goods are values the significance of which is irreducible to some contribution to or constituent of individual well-being; one might think that the value of a just or a solidaristic community, for example, does not reduce to the contributions its justice and solidarity make to its members' well-being. Collective goods are a subset of impersonal goods, but can be thought of in one of two ways. Either we could argue that (some) groups of people can have interests distinct from and irreducible to the interests of their constituent members. Or we could argue that the advancement of (some) groups is impersonally valuable, without making the metaphysical claim that a group can have interests. Either way, if wars are not fought only for individual interests, then we need some account of precisely what the other values at stake are. ${ }^{45}$

Both impersonal and collective values are philosophically fraught. ${ }^{46}$ The thesis that nothing has value besides the constituents of individual well-being is both plausible in itself, and widely assumed in moral and political philosophy. Demonstrating that there are indeed other sources of moral reasons besides individual interests is difficult enough; showing that these are sufficiently weighty to justify killing innocent people is a further stretch still. However, if we want to retain our common-sense view of a political community's right to defend itself against purely political aggression, then I think we need to forge some argument along these lines. Moreover, we need to do so without proving too much: the view that collective or impersonal goods can justify overriding individual interests has been the normative opening for some of history's worst atrocities. Reclaiming these arguments from their history of heinous abuse is a profound challenge in itself.

The second positive requirement is an extension of the first, identifying the descriptive terrain in which the values that are worth killing for must be discovered. Wars

\footnotetext{
${ }^{45}$ McMahan never added to this, but he recognized it in an earlier paper: 'Extrapolation has to proceed by composition rather than by analogy, but even the most reductive form of individualism must take account of distinctively collective goods, such as collective self-identification or collective self-determination, and thus recognize that there may be wrongs that are not entirely reducible to wrongs against individuals because they have a collective as their subject.' Jeff McMahan, 'Just Cause for War', Ethics \& International Affairs, 19/3 (2005), 1-21: 12. In this volume, Moore and Kutz in particular attempt to give some account of what other values are at stake in war, besides individual rights.

${ }^{46}$ For discussion of impersonal value in the context of distributive justice, see e.g. Andrew Mason, Community, Solidarity and Belonging: Levels of Community and Their Normative Significance (Cambridge: Cambridge University Press, 2000); Andrew Moore and Roger Crisp, 'Welfarism in Moral Theory', Australasian Journal of Philosophy, 74/4 (1996), 598-613; Larry S. Temkin, 'Harmful Goods, Harmless Bads', in R. G. Frey and Christopher W. Morris (eds.), Value, Welfare, and Morality (Cambridge: Cambridge University Press, 1993), 290-324.
} 
of national defence, especially against purely political aggression, are fought in part to preserve a particular institutional arrangement, whereby one political community has political control over a given territory and its population. If we think wars against purely political aggression can be justified, and that even in regular wars of national defence, preserving the present institutional arrangement plays some justificatory role, then we need to explain why preserving this institutional arrangement matters. This is the site of the collective and impersonal values identified in the first requirement. Three interrelated lines of argument could be developed (again, they need not be mutually exclusive). The first focuses on why political communities have value, and in particular, the sort of value that is worth killing to preserve. It can proceed by examining both the internal qualities of the community, for example its achievement of justice, ${ }^{47}$ or a vibrant solidarity, and its external qualities-for example, how it contributes to maintaining an internationally stable system. The second line would be to ask why it should matter that political communities should be independent from outside interference (beyond some threshold) ${ }^{48}$ Why should we care about the survival and independence of political communities that are often historically contingent? Does it matter only insofar as it allows the political community to achieve the values identified in the first line of argument, or is there some distinct value in the community achieving these goods in their own way? The third line of argument starts with the observation that, to arrive at a plausible view of national defence, we would need to ask not only why it matters that this group of people should be able to determine their collective existence together, but also why they should do so in this particular place, on this territory. Purely political aggression undermines the victim community's independence, but it does so by taking control of territory in particular. Does this territorial dimension matter? ${ }^{49}$ Is there an important connection between the political community and the specific territory it happens to occupy? Can this be understood in individualist terms, or do we need to appeal to collective or impersonal values to explain why retaining control of this particular territory should matter so much?

The final positive requirement is that the exceptionalist justification for national defence should be to some degree partialist. It should explain why the value that is worth fighting for in wars of national defence is in part relative to the identity of the agents doing the fighting. To see why, consider the following example. Two countries are involved in a conflict of disputed origin over a contested territory. Whether they are justified in fighting depends in part on the set of collective and/or impersonal goods alluded to above. Suppose that one community better instantiates these values than the other. Does it follow that citizens of the less valuable community are not justified in defending themselves - that they must concede to the more valuable community? If

\footnotetext{
47 See Seth Lazar, 'A Liberal Defence of (Some) Duties to Compatriots', Journal of Applied Philosophy, 27/3 (2010), 246-57. Also Kutz, chapter 10 in this volume.

${ }^{48}$ See Moore, chapter 8 this volume.

${ }^{49}$ See Stilz, chapter 9 in this volume.
} 
we construed the values at stake impartially, then this would follow, but it appears obviously implausible. Presumably, our community must meet some threshold of value to be worth fighting for, but once it meets that threshold, then we are entitled to fight for our own community, even if the adversary community is more valuable in every way.

A viable exceptionalist justification for national defence would also have to meet at least two negative desiderata. First, it must either explain why the principles of ordinary interpersonal morality do not apply in war, or it must show that its arguments operate in addition to ordinary moral principles, not instead of them. The first path is unlikely to be an easy one. Reductionists can quite reasonably insist that even if their account does not cover the whole scope of the ethics of war, absent some compelling argument to the contrary we must surely acknowledge that the principles governing the use of force outside of war still in large part apply. Showing the opposite would mean arguing that the initiation of conflict between large groups of belligerents also initiates a fundamental and profound change in the moral protections that people enjoy against suffering harm. Although such an argument can be made, it would require a tremendous amount of work to be convincing..$^{\circ}$ One possible approach is to deny that we enjoy these protections except in an institutional context, and then argue that the shift in institutional context from ordinary life to war changes the protections that we enjoy. ${ }^{51}$ But it is quite implausible to suggest that, absent an institutional context, we can kill innocent people without wrongdoing.

If the exceptionalist cannot show that reductionist principles are irrelevant to war, she must show how her theory incorporates those principles. Of course, she must also identify further values that can override the considerations identified by a reductionist account, or go beyond what they alone would permit. But those considerations will remain relevant to the morality of war, and might indeed still carry a considerable explanatory and justificatory weight.

The second negative desideratum is complementary to the first. Just as the exceptionalist must either explain why the ordinary principles governing the use of force do not apply in war, or else incorporate them into her account, so she must either explain why the exceptionalist principles to which she appeals to justify war do not apply outside of wartime, or show that although they are relevant in ordinary life, they do not have troubling and untenable implications in other contexts. This is particularly true of the appeal to collective or impersonal values: if they can justify killing in war, then are there other circumstances outside of war when they can justify killing? What are the implications of adopting views such as these about war for our attitude to national liberation movements, and political secession, for example? If the values that we appeal to, in order to justify and explain our judgments about national defence,

\footnotetext{
5o Some of that work is being done in this book, by Benbaji, chapter 7 .

${ }^{51}$ One could draw inspiration here from Allen Buchanan and Robert O. Keohane, 'The Preventive Use of Force: A Cosmopolitan Institutional Proposal', Ethics \& International Affairs, 18/1 (2004), 1-22.
} 
have problematic implications in these other areas, then we might be forced to accept a wholly reductionist approach as the lesser of two evils.

\subsection{Conclusion}

Our ordinary view of the ethics of war grants states the right to use lethal force to resist purely political aggression by other states. Providing an adequate philosophical foundation for this political defensive privilege, however, proves remarkably tricky. The most natural way for philosophers to approach the justification of killing in war-to see it as a particular case, to which general principles governing permissible killing can be applied-has proven inadequate to the task, at least on some very plausible assumptions. If I am right that wars cannot be fought without killing the innocent, and that individuals' interests in their state's retaining political control of some territory are not vital, then the most permissive plausible version of reductionism cannot justify national defence against a purely political threat, since it cannot endorse killing the innocent to preserve less than vital interests. This could spell the end either for reductionism, or for the political defensive privilege. I considered whether reformulating the reductionist position would resolve the problem, but it led either to implausible views about the relation between population size and the scope and weight of the political defensive privilege, or to a rule-consequentialist position that is not meaningfully reductionist. If we want to retain the political defensive privilege, we need to look beyond reductionist arguments to an exceptionalist account of the legitimate purposes of military force. We need to ask why political independence is worth fighting for, and show that it matters not only because of its contribution to the interests of the individual members of the political community, but in some irreducible impersonal and/ or collective sense as well. We need to show why this value matters enough to justify killing the innocent in war, without proving too much. And we need to show how this exceptionalist framework for war's morality either supersedes or complements the reductionist principles with which we began. The task is formidable, but necessary if we are to make sense of our pre-theoretical beliefs about the ethics of war. 